\title{
The Influences of Principal's Academic Supervision, Organizational Climate and Teacher's Work Motivation on Teacher's Performance in The Al-Hamidiyah Islamic Education Foundation, Depok
}

\author{
Dwi Alfiani Rusmawati ${ }^{1}$, Abdul Rahman A.Ghani ${ }^{2}$, Ihsana El Khuluqo ${ }^{3}$. \\ Sekolah Pascasarjana Universitas Muhammadiyah Prof. DR. HAMKA, Jakarta, Indonesia \\ alfirusmawati@gmail.com¹, rahman.ghani@uhamka.ac.id²,ihsana_khuluqo@uhamka.ac.id³
}

\begin{abstract}
This research was conducted on May, 2020 with the aim of analyzing, testing and knowing the the influence of principal's academic supervision, the organizational climate, and teacher's work motivation, on the teacher's performance in the Al Hamidiyah Islamic Education Foundation, Depok. The sampling technique used was a questionnaire, in which the entire population numbered 192 people with a sampling technique used is a proportionate stritified random sampling technique of 130 people. The data analysis method used is path analysis with a simple linear correlation approach. The quantitinive research data collection uses a research instrument with a Likert scale while the validity test of the instrument uses the Pearson Product Moment correlation coefficient formula and the reliability test of the research instrument uses the Cronbach Alpha formula. To test the analysis requirements we used the Kolomogorov-Smirnov normality test and the Levena homogeneity test. The results of data analysis with a simple linear regression stinistical test using the SPSS application show that 1) There is a positive direct the influence of Principal's academic supervision on teacher's work motivation so that if the Principal's academic supervision rises by 0.947 it will be followed by an increase in teacher's work motivation by $5,921,2$ ) There is positive direct the influence of the organizational climate on teacher's work motivation so that if the organizational climate rises by 0.975 it will be followed by an increase in teacher's work motivation by $3,777,3$ ) There is a positive direct positive the influence on Principal's academic supervision on teacher's performance so thin if the Principal's academic supervision rises by 0.825 it will followed by an increase in teacher's performance by $1,668,4)$ There is a positive direct the influence on the organizational climate on teacher's performance so that if the organizational climate rises by 0.865 it will be followed by an increase in teacher's performance by $14,911,5)$ There is a positive direct the influence on teacher's work motivation to teacher's performance so that if the teacher's work motivation increases by 0.887 it will be followed by an increase in teacher's performance by 12,444 , 6) There is a positive direct the influence of Principal's academic supervision on the organizational climate so that if the Principal's academic supervision rises by 0.913 it will be followed by an increase in organizational climate as large as 9,269 . It is recommended to the Al Hamidiyah Islamic Foundation Depok to improve teacher's performance through enhancing the Principal's academic supervision, creating a conducive the organizational climate and fostering teacher's work motivation.
\end{abstract}

Keywords: Principal's academic supervision, the organizational climate, teacher's work motivation, teacher's performance. 


\section{INTRODUCTION}

In Law Number 20 of 2003 Article 1 paragraph (3) [1], it is stated that the national education system is an entire component of education that interacts continuously, complements and is integrited in an educational process to achieve national education goals. In order for schools to have high competitiveness on a global scale, these organizations must be able to do a better, more the influenceive and efficient job of producing high quality output in competitive prices through good human resource management.

Based on the observations conducted, teachers in the Al Hamidiyah Islamic Education Foundation Depok units need to optimize their performance more so that they are better, because some teachers do not have the awareness to take part in various educations and trainings to improve self-competence. It can also be seen in the performance display, there is still a lack of teacher's behavior to have self-encouragement to achieve work results and learning objectives the influenceively.

This research was conducted in the Al Hamidiyah Islamic Education Foundation Depok in the early childhood, primary and secondary education units; namely: KB / TK, SDIT, SMPI, MTs and MA with school statistics for the 2019/2020 learning year as follows:

TABLE 1. School Statistics Data

\begin{tabular}{|l|c|c|c|c|c|c|}
\hline \multicolumn{1}{|c|}{ ELEMENTS } & TK & SDIT & SMP & MTs & MA & AMOUNT \\
\hline Number of Teachers & 26 & 79 & 27 & 32 & 28 & 192 \\
\hline Education Personnel & 2 & 3 & 3 & 4 & 4 & 16 \\
\hline Certified Teachers & 15 & 18 & 5 & 19 & 14 & 71 \\
\hline Number of Students & 218 & 829 & 336 & 363 & 279 & 2025 \\
\hline Number of Classes & 10 & 29 & 12 & 14 & 12 & 77 \\
\hline
\end{tabular}

\section{THEORITICAL STUDIES}

Gibson in Kashmir [2] said that "Individual performance is the basis of organizational performance which is strongly influenced by individual characteristics, individual motivation, expectations and assessments made by management on the achievement of individual work results".

Robbins quoted by Kashmir [2], said that "Performance is a function of the interaction between ability, motivation and opportunity."

Sergiovanni in Priansa [3] said that "The practical reflection of teacher performance appraisal in academic supervision is seeing the real conditions of teacher performance to answer questions, what happens in class, what teachers and students do in class, which activities are meaningful for teachers and students in the classroom, what has the teacher done in achieving academic goals, what are the strengths and weaknesses of the teacher and how to develop it. Even so, the essence of academic supervision is not only to assess the performance of teachers in managing the learning process, but also to help teachers develop their professional abilities."

Erjati Abas [4] said that "Performance has a close relationship with productivity problems, because it is an indicator in determining how efforts to achieve high levels of productivity in organizations, so productivity is the range between output and input."

The criteria for teacher's performance that are categorized as achieving their work results are more directed in teacher competence as stated in the explanation of Government Regulation Number 19 of 2005 concerning National Education Standards [5], and Regulation of the Minister of National Education Number 16 of 2007 concerning Academic Qualification Standards and Teacher Competence [6], that teacher performance in this case the competence of teachers includes four competency dimensions, namely: pedagogic, personality, professional and social with the following dimensions:

a. Dimensions of pedagogical competence, with indicators: 1) Understanding the insight or foundation of education, 2) Understanding students, 3) Developing curriculum and syllabus, 4) Planning learning, 5) Implementing learning, 6) Evaluating learning outcomes, 7) Developing students to actualize the various potentials it has.

b. Dimensions of personality competence, with indicators: 1) stable, 2) noble character, 3) being a role model for students and society, 4) evaluating one's own performance, 5) developing yourself sustainably.

c. Dimensions of professional competence, with indicators: 1) Mastering the material in depth: concepts, structures, methods that are coherent with teaching materials, 2) Mastering material according to the school curriculum, 3) Mastering the application of scientific concepts in everyday life, and 4) Knowing the conceptual relationship between 
related subjects.

d. Dimensions of social competence, with indicators:

1) using communication and information technology

functionally, 2) associatining the influenceively with

One of the duties of the Principal is to carry out academic supervision activities, as mandated in the Regulation of the Minister of National Education Number 13 of 2007 concerning Principal Standards [7]. Academic supervision carried out by the Principal is an action designed by the Principal to assist teachers in the form of controlling and coaching in the academic field through learning activities and processes in schools in order to achieve learning objectives; as part of the teacher performance assessment based on the principles of supervision.

According to Sergiovanni in Priansa [3], a practical reflection of teacher performance appraisal in academic supervision is to see the real conditions of teacher performance to answer questions: what happens in class, what teachers and students do in class, which activities are meaningful to the teacher and students in the class, what teachers do in achieving academic goals, what are the strengths and weaknesses of teachers and how to develop them. However, the essence of academic supervision is not only assessing teacher performance but also helping teachers develop their professional abilities.

Ghani [8] mentions that the details of the main duties of the Principal's supervision are monitoring, assessing, fostering, reporting and following up. The principal's academic supervision has the following dimensions:

a. Dimensions to achieve educational goals, through: 1) Research: Monitoring the implementation of learning / learning outcomes guidance and monitoring the applicability of the curriculum for each subject. 2) Assessment: Assessing the teacher's ability to carry out the learning / guidance process. 3) Improvement: Fostering teachers in compiling syllabus and lesson plans, fostering teachers in carrying out learning in class / laboratory / field, fostering teachers in creating, managing, using educational and learning media, fostering teachers in utilizing assessment results to improve the quality of education, fostering teachers in processing and analyzing the assessment data. 4) Coaching: Report and follow up on academic supervision to improve teachers' professional abilities.

b. Dimensions to assist teachers in: 1) Planning lessons 2) Presentation of learning minerials 3) Evaluating learning 4) Managing class 5) Developing curriculum 6) Evaluating themselves 7) Working closely with groups. students, fellow educators, education staff and parents of students, 3) socializing politely with the surrounding community.

Wirawan [9] said that "Organizinional climate is the perception of organizational members and those who are regularly connected with the organization about what is or happens in the organizational environment on a regular basis that affects organizational attitudes and behavior and the performance of organizational members which then determines organizational performance."

Martini and Yuliano [10] in the journal Volume 2 No. 9 argue that "Organizational climate reflects the internal conditions of an organization because climate can only be felt by members of the organiziation, and climate can be a means to find the causes of negative behavior that occurs in employees."

Meanwhile, Syaiful Sagala [11] said that "Organizational climate is a series of work environments, which are assessed directly or indirectly by employees who are considered to be the main force in influencing employee behavior."

Organizational climate is the internal atmosphere felt by members during activities, which can affect the attitudes and behavior of the organization and the performance of its members in achieving organizational goals. The organizational climate in schools appears in the following dimensions:

a. The dimensions of the Principal's behavior, with the

following indicators: 1) Supportive, is the behavior of the principal directed in social needs and work performance. The principal is helpful, really cares about the teacher, and seeks to motivite by using constructive criticism and by setting an example through hard work. 2) Directive, is the rigid behavior of the principal. Principals constantly monitor almost all aspects of teacher behavior in schools. 3) Restrictive, is the behavior of the principal that limits the work of teachers rather than facilitating it. Principals burden teachers with administrative work, and other demands that interfere with teaching responsibilities.

b. The dimensions of teacher behavior, with indicators: 1) Collegial, is teacher behavior that is open and supports interactions between teachers in a professional manner. Such as mutual respect and help each other both personally and professionally. 2) Committed, is teacher behavior that is directed to assist students in developing intellectual and social abilities. Teachers go the extra mile to ensure student success in school. 3) Disengaged is the behavior of teachers who are less focused and 
meaningful for professional activities.

Bimo Walgito [12] defines motivation as a force contained in an organism that encourages action or is a driving force.

Meanwhile, Sondang Siagian [13] said that "Motivation is a driving force that results in someone willing and willing to expert their abilities in the form of expertise, energy and time to carry out various activities thin are their responsibility and fulfill their obliginions in order to achieve predetermined goals."

Mangkunegara in Kompri [14] said that "Motivation is formed from one's intitude in facing work situations. A positive mental intitude of employees towards work situations will streng then their work motivation to achieve maximum performance. "Teacher work motivation is an encouragement that comes from inside and outside the teacher to devote energy, thoughts and feelings to completing work responsibly in order to achieve quality work results.

Asnawi Sahlan [15] mentions several experts who convey theories of motivation, including: 1) The theory of social motivation by Mc Clelland, 2) The theory of needs motivation by Abraham Maslow, 3) The theory of contemporary motivation approaches by Mc Gregor, and 4) The theory of reward and achievement motivation by F Herzberg.

According to Erjati Abas [4], teacher work motivation is an encouragement in a teacher to carry out his duties and responsibilities with enthusiasm, in an effort to achieve goals more optimally.

Ratu Ile Tokan [16] said that advances in science and technology have supplied various accesses so thin the pedagogical process must be more outcome oriented, not output oriented. On the other hand, the need for a teacher as an adult in learning (the concept of andragogy) is essentially a change in the concept of thinking, mindset, paradigm, experience, increased skills, a change in behavior that is more ethical and wise. But in reality, teachers generally do not have a strong internal motivation to meet these changes so thin external motivation needs to be built with the right strategy.

The factors that can lead to teacher work motivation are as follows:

a. The dimensions of intrinsic motivation, namely: 1) Achievement, is a person's success in completing tasks, facing problems or overcoming challenges. 2) Appreciation / recognition, is the behavior shown to someone as a manifestiation of the intention of others. 3) Improvement, is a person's opportunity to occupy a higher position. 4) Responsibility is the granting of authority to someone to carry out tasks in repair. 5) The job itself, the accure of the job that causes a reaction from one's intitude to carry out the task happily.

b. The dimensions of extrinsic motivation, namely: 1) Working conditions, namely working conditions including the physical work environment, facilities and infrastructure. 2) Interpersonal relinionships, namely relationships between people in the work environment. 3) Policy and administration, namely the way policies are used in organizations to regulate work. 4) Salary, namely the income that a person earns in the form of money. 5) Job security, which is guarantee to creine a sense of security in work.

\section{PROBLEMS ASSESSED}

This research is designed and implemented to collect, analyze data, test and find out:

1) The direct influence of the principal's academic supervision on teacher's work motivation in the Al Hamidiyah Islamic Education Foundation, Depok.

2) The direct influence of organizational climate on teacher's work motivation in the Al Hamidiyah Islamic Education Foundation, Depok.

3) The direct influence of the principal's academic supervision on teacher's performance in the $\mathrm{Al}$ Hamidiyah Islamic Education Foundation, Depok.

4) The direct influence of the organizational climate on teacher's performance in the Al Hamidiyah Islamic Education Foundation, Depok.

5) The direct influence of teacher's work motivation on teacher's performance in the Al Hamidiyah Islamic Education Foundation, Depok.

6) The direct influence of the Principal's academic supervision on the organizational climate in the $\mathrm{Al}$ Hamidiyah Islamic Education Foundation, Depok.

\section{RESEARCH METHODS}

This study uses a quantitinive approach. Emzir [17] said that quantitinive research is research conducted primarily using a postpositive paradigm in developing science using research strategies that require statistical data.

Sugiyono [18] argues that in quantitinive research the relationship between variables is causal, so that in his research there are independent variables and dependent variables. And because researchers do not interact with data sources, so the data obtained is objective.

Researchers use instruments to collect data that will be used to measure the value of the variable under study. The data collected were the school principal's academic supervision variable data, organizational 
climate variable data, teacher's work motivation variable data and teacher's performance variable data, using the instrument as a data collection technique. The research instrument is used to measure the value of the variable under study and the number of instruments depends on the number of variables studied.

Because research instruments are used to take measurements with the aim of producing accurate quantititive data, each instrument must have a scale. The measurement scale is an agreement that is used as a reference for determining the length and shortness of the intervals in the measuring instrument, so that the measuring instrument when used in measurement will produce quantitive data.

According to Sukardi [19], "Likert scale has been widely used by researchers to measure a person's perception or intitude desired by researchers by asking several questions to respondents. Then the respondent is asked to provide answer choices on the measurement scale that has been provided, for example strongly agree, agree, doubt, disagree and strongly disagree. "

With a Likert scale, the variables to be measured are transleted into variable indicators, then used as a starting point for arranging instrument items that can be statements or questions. To facilitate the preparation of instruments, an instrument development matrix or instrument grid is used.

To score a Likert category scale, positive statement answers are weighted or equalized to the value for the need for quantitive analysis, then the answer can be scored, for example: Strongly Agree given a score of 5, Agree given a score of 4, Doubt given a score of 3, Disagree given a score 2, and Strongly Disagree was given a score of 1 .

Where as negative statements are given the opposite weight, for example: Strongly Agree is given a score of 1 , Agree is given a score of 2, Doubt is given a score of 3 , Disagree is given a score of 4 , and Strongly Disagrees is given a score of 5 .

In this study, researchers used instruments with positive and negative statements that were randomly generated to determine the accuracy of respondents in reading and filling out questionnaires so that respondents could answer seriously and consistently. This method is used so that the tendency of respondents to answer in certain columns of the checklist form can be reduced.

Before being used as an instrument, it must first be tested for the validity and reliability of the instrument so that the research results are valid and reliable. A valid instrument means thin the measuring instrument used to obtain the data is appropriate to measure what should be measured. A reliable instrument is an instrument that, when used several times to measure the same object, will produce the same data.

The instrument validity tes of this research using the Pearson Product Moment correlation coefficient formula to determine the correlation between the item score and the total score with the formula:

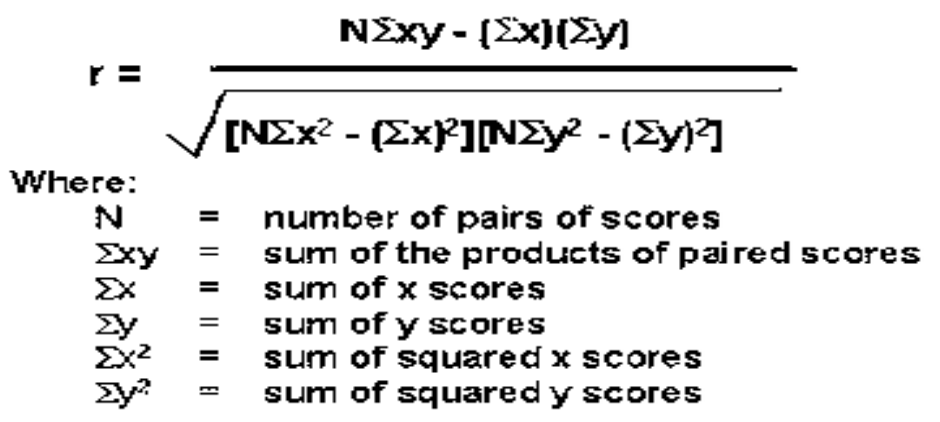

The research instrument reliability used the Alpha Cronbach formula, namely: 
- Cronbach's basic equation for alpha

$$
\alpha=\frac{n}{n-1}\left(1-\frac{\sum V i}{V t e s t}\right)
$$

\section{$-\mathbf{n}=$ number of questions \\ - Vi $=$ variance of scores on each question \\ - Vtest $=$ total variance of overall scores on the entire test}

Instrument testing was carried out on 30 respondents outside the sample who were included in the population.
From the instrument trial, the following results were obtained:

TABLE 2. Instrument Testing Results

\begin{tabular}{|l|c|c|c|}
\hline \multicolumn{1}{|c|}{ Variable } & Number of Items & $\begin{array}{c}\text { Items } \\
\text { Drop }\end{array}$ & $\begin{array}{c}\text { Number of } \\
\text { Instruments }\end{array}$ \\
\hline Teacher's Performance & 38 & 2 & 36 \\
\hline Principal's Academic Supervision & 33 & 4 & 29 \\
\hline The organizinional Climate & 36 & 4 & 32 \\
\hline Teacher's Work Motivation & 33 & 8 & 25 \\
\hline Total & 140 & & 122 \\
\hline
\end{tabular}

This research was conducted on May 2020 with the aim of examining and analyzing the the influence of principal's academic supervision, the organizational climate, and teacher's work motivation on teacher's performance in the Al Hamidiyah Islamic Education Foundation, Depok. The sampling technique used was using a questionnaire and data collection techniques using the google form facility, the researcher made a questionnaire that was entered into the application, then created a URL that was sent to each respondent's email. Respondents who have filled out the questionnaire and submitted answers that are directly received by the researcher so that objectivity is maintained.

\section{RESULTS AND DISCUSSION}

\subsection{Research Result}

This research is a descriptive correlational study conducted with the aim of describing or describing whether there is and the level of the relationship between two or more variables. The researcher did not manipulate the state of the existing variables and immediately looked for the existence of the relationship and the level of the relationship between the variables as reflected in the correlation coefficient.

The population was 192 people. The sampling technique used the Slovin formula with a proportionate stritified random sampling technique of 130 people.

To test the analysis requirements, the Kolomogorov-Smirnov normality test and the Levena homogeneity test were used with the following results:

TABLE 3. Normality Test Results

\begin{tabular}{|l|c|}
\hline \multicolumn{1}{|c|}{ Variables } & Normality Test Variables \\
\hline Teacher's Performance & 0,2 \\
\hline Principal's Academic Supervision & 0,067 \\
\hline The organizational Climate & 0,083 \\
\hline Teacher's Work Motivation & 0,074 \\
\hline
\end{tabular}


From the normality test above, all variables are normally distributed, and the homogeneity test shows that all variables are homogeneous.

The data description can be described as follows:

TABLE 4. Data Descryption

\begin{tabular}{|l|c|c|c|c|}
\hline \multicolumn{1}{|c|}{ UNSUR } & $\begin{array}{c}\text { Teachers's } \\
\text { Performance }\end{array}$ & $\begin{array}{c}\text { Principal Academic } \\
\text { Supervision }\end{array}$ & $\begin{array}{c}\text { Organizinional } \\
\text { Climate }\end{array}$ & $\begin{array}{c}\text { Teacher's Work } \\
\text { Motivation }\end{array}$ \\
\hline Validity & 36 & 29 & 32 & 25 \\
\hline Reliability & 0,928 & 9,935 & 0,918 & 0,898 \\
\hline Mean & 143,68 & 121,35 & 108,62 & 103,88 \\
\hline Median & 146 & 122,5 & 109 & 105 \\
\hline Mode & 150 & 137 & 112 & 117 \\
\hline $\begin{array}{l}\text { Standard } \\
\text { Devation }\end{array}$ & 7,653 & 13,471 & 5,04 & 9,55 \\
\hline Lowest Score & 125 & 87 & 94 & 76 \\
\hline Highest Score & 158 & 139 & 119 & 120 \\
\hline Range & 33 & 52 & 25 & 44 \\
\hline
\end{tabular}

\subsection{Discussion}

The data analysis method used is path analysis with a simple linear correlation approach:

\section{Hypothesis 1}

The results of the data analysis of the first hypothesis testing in this study with a simple linear regression statistical test using the SPSS application obtained the simple linear regression coefficient price of the principal's academic supervision (b) on teacher's work motivation of 0.947 with a constant (a) of 4.974 So the simple linear regression equation is $\hat{Y} 1=a+b X$ $=4.974+0.947 \mathrm{x}$, the significance value of 1.046 is greater than 0.05 , so there is a direct positive influence of the principal's academic supervision on teacher's work motivation in the $\mathrm{Al}$ Hamidiyah Islamic Education Foundation, Depok. T count of 18.95 is greater than $t$ table of 1.645 , so the significant influence and $\mathrm{R}$ square value is 0.737 . This value implies that the the influence of the principal's academic supervision on teacher's work motivation is $73.7 \%$, while $26.3 \%$ teacher's work motivation is influenced by other variables not examined.

The results of this study are in accordance with the research conducted by Edi Rismawan [20] which said that the supervision of the principal has an influence on teacher achievement motivation.

The results are consistent with research conducted by Hansen Gunawan, et al.[21] which shows there was a direct and significant influence of academic supervision of principal, job satisfaction and work motivation on teacher's performance.

The results of this study are in accordance with the research conducted by Ghani, Herlina.[22].

\section{Hypothesis 2}

The results of the data analysis of the second hypothesis testing in this study with a simple linear regression statistical test using the SPSS application obtained a simple linear regression coefficient price of organizational climate (b) of 0.975 with a constant (a) of 2.802. So that the simple linear regression equation is $\hat{Y} 1=a+b X=2.802+0.975 x$ the significance value of 1.018 is greater than 0.05 . It can be concluded that $\mathrm{Ho}$ is rejected and $\mathrm{H} 1$ is accepted, so it can be concluded that there is a positive direct influence of the organizational climate on teacher's work motivation in the Al Hamidiyah Islamic Education Foundation, Depok. T count of 44.718 is greater than $t$ table of 1.645 , so the influence is significant and the R square value is 0.94 . This value implies thin the influence of the organizatioal climate on teacher's work motivation is $94 \%$ while $6 \%$ of teacher's work motivation is influenced by other variables which are not examined.

The results of this study are consistent with research conducted by NE Rohmawati [23] which shows that organizational climate has a high influence on teacher's performance.

\section{Hypothesis 3}

The results of the data analysis of the third hypothesis testing in this study with a simple linear regression statistical test using the SPSS application obtained a simple linear regression coefficient price for the principal's academic supervision (b) of 0.843 with a constant (a) of 15.635 So that the simple linear regression equation is $\hat{Y} 1=a+b X=0.843+0.825 x$ the significance value of 0.944 is greater than the significance value of 0.05 so that $\mathrm{Ho}$ is rejected and $\mathrm{H} 1$ is accepted. It is concluded that there is a positive 
direct influence of the principal's academic supervision on teacher's performance in the Al Hamidiyah Islamic Education Foundation, Depok. The t count of 16.533 is greater than the $\mathrm{t}$ table of 1.645 so that it has a significant influence and the $\mathrm{R}$ square value is 0.681 . This value implies that the influence of the principal's academic supervision on teacher's performance is $68.1 \%$, while $31.9 \%$ of teacher's performance is influenced by other variables not examined.

The results of this study are in accordance with research conducted by Supardi [24] which shows that increased supervision will be followed by an increase in teacher performance of 0.91 and an increase in work climate will be followed by an increase in teacher's performance by 0.72 .

\section{Hypothesis 4}

The results of the data analysis of the fourth hypothesis testing in this study with a simple linear regression statistical test using the SPSS application obtained a simple linear regression coefficient price for the organizational climate (b) of 0.865 with a constant (a) of 14.046 So that the simple linear regression equation is $\hat{\mathrm{Y}} 1=\mathrm{a}+\mathrm{bX}=14.046+0.865 \mathrm{x}$, the significance value of 0.925 is greater than 0.05 . It is concluded thin $\mathrm{Ho}$ is rejected and $\mathrm{Ha}$ is accepted, which means that there is a positive direct influence of the organizational climate on teacher's performance in the Al Hamidiyah Islamic Education Foundation, Depok. The $t$ count of 28.374 is greater than the table of 1.645 so that the significant influence and the $\mathrm{R}$ square value is 0.863 . This value implies that the influence of the principal's academic supervision on teacher's performance is $86.3 \%$, while $13.7 \%$ of teacher's performance is influenced by other variables that are not examined..

The results of this study are in accordance with research conducted by Micha Felayati et al. [25] on the The influence of Organizational Climate and Job Satisfaction on the Performance of Guidance and Counseling Teachers.

\section{Hypothesis 5}

The results of the data analysis of the fifth hypothesis testing in this study using simple linear regression statistical tests using the SPSS application obtained a simple linear regression coefficient price for the organizational climate (b) of 0.887 with a constant (a) of 11.557 So that the simple linear regression equation is $\hat{\mathrm{Y}} 1=\mathrm{a}+\mathrm{bX}=11.557+0.887 \mathrm{x}$ the significance value of 0.993 is greater than 0.05 . It can be concluded that there is a positive direct influence of teacher's work motivation on teacher's performance in the Al Hamidiyah Islamic Education Foundation, Depok. T count of 37.742 is greater than t table of 1.645 so that the significant influence and $\mathrm{R}$ square value is 0.918 . This value implies that the influence of teacher's work motivation on teacher's performance is $91.8 \%$, while $8.2 \%$ of teacher's performance is influenced by other variables which are not examined.

The results of this study are consistent with research made by Ika Rahmawati [26], which said that school climate and work motivation have an the influence on teacher's performance. Also consistent with research conducted by Suryati, et al. [27] that there is influence work motivation and work climate on the teacher's performance simultaneously.

\section{Hypothesis 6}

The results of the data analysis of the sixth hypothesis testing in this study with a simple linear regression statistical test using the SPSS application obtained a simple linear regression coefficient price for the principal's academic supervision (b) of 0.913 with a constant (a) of 8.356 So the simple linear regression equation is $\hat{\mathrm{Y}} 1=\mathrm{a}+\mathrm{bX}=8.356+0.913 \mathrm{x}$, the significance value is 1.019 which is greater than 0.05 . It can be concluded that there is a positive direct influence of the Principal's academic supervision on the organizational climate in the $\mathrm{Al}$ Hamidiyah Islamic Education Foundation, Depok. T count of 16,987 is greater than $t$ table of 1,645 so that the significant influence and $\mathrm{R}$ square value is 0.693 . This value implies that the influence of the principal's academic supervision on the organizational climate is $69.3 \%$, while $30.7 \%$ of teacher's performance is influenced by other variables not examined.

The results of this study are consistent with research conducted by Femi Andi Rizki Pratami et al. [28], that there is influence of principal and organizational climate supervision on teacher's performance in Bukit, Palembang.

Based on the calculation of the correlation statistical analysis and path analysis, the results are shown in the following figure: 


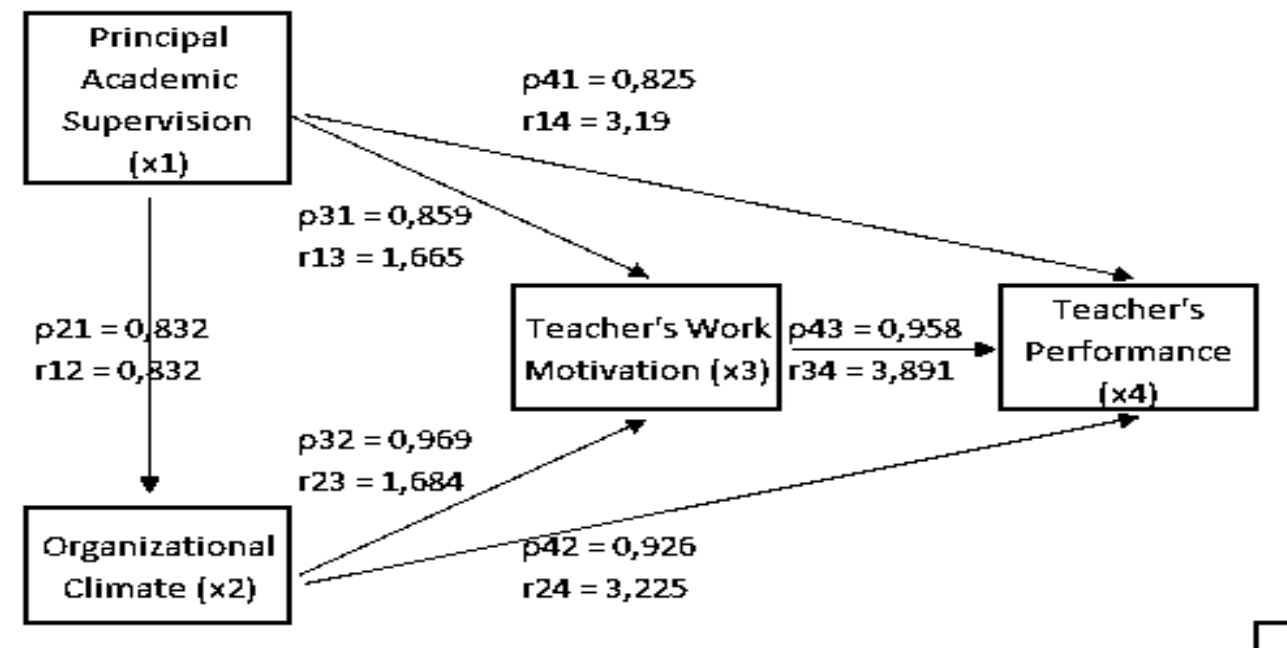

FIGURE 1.

Research Results

\section{CONCLUSIONS RECOMMENDATIONS}

\subsection{Conclusions}

Researchers can draw the following conclusions:

1. Principal's academic supervision has a positive direct influence on teacher's work motivation. From the calculation results obtained a correlation coefficient of 0.947 and a constant of 4.947 and a significant level of 1.046. The results of this study indicate that the principal's academic supervision contributes $73.7 \%$ to teacher's work motivation.

2. The organizational climate has a positive direct influence on teacher's work motivation. From the calculation results obtained a correlation coefficient of 0.975 and a constant of 2.802 and a significance level of 1.018. The results of this study indicate the contribution of the organizational climate by $94 \%$ to teacher's work motivation.

3. Principal's academic supervision has a positive direct the influence on teacher's performance. From the calculation results obtained a correlation coefficient of 0.843 and a constant of 15.635 . The results of this study indicate that the principal's academic supervision contributes $68.1 \%$ to teacher's performance.

4. The organizational climate has a positive direct influence on teacher's performance. From the calculation results obtained a correlation coefficient of 0.865 and a constant of 14.046. The results of this study indicate the contribution of the organizatioal climate by $86.3 \%$ to teacher's performance.

5. Teacher's work motivation has a positive direct influence on teacher's performance. From the calculation results obtained a correlation coefficient of 0.887 and a constant of 11.557. The results of this study indicate the contribution of teacher's work motivation by $91.8 \%$ to teacher's performance.

6. Principal's academic supervision has a positive direct influence on the organizational climate. From the calculation results obtained a correlation coefficient of 0.913 and a constant of 8.356. The results of this study indicate that the principal's academic supervision contributes $69.3 \%$ to the organizational climate.

\subsection{Recommendations}

Based on the conclusions and implications above, it can be recommended as follows:

a. Al-Hamidiyah Islamic Education Foundation, Depok, is to make efforts to improve teacher's performance through improving the quality of the Principal's academic supervision and monitoring and evaluating the academic supervision carried out by the Principal so as to create a conducive organizational climate in order to improve teacher's performance.

b. Principal of the Al-Hamidiyah Islamic Education Foundation, Depok, is to carry out a process of research, assessment, improvement and coaching of teachers so that teachers improve their performance and create an organizational climate that can increase teacher's motivation and performance.

c. Teachers in the Al-Hamidiyah Depok Islamic 
Education Foundation Depok is to improve competence, create behavior that can lead to a good organizational climate so that it can foster work motivation in order to improve performance.

\section{REFERENCES}

[1] Undang-Undang Nomor 20 Tahun 2003 Tentang Sistem Pendidikan Nasional.

[2] Kashmir, Manajemen Sumber Daya Manusia, Teori dan Praktik (Rajawali Press, Depok, 2018), pp. 182-183.

[3] Priansa, Manajemen dan Supervisi Pendidikan (Pustaka Setia, Bandung, 2018), pp. 218.

[4] Abas, Erjati, Magnet Kepemimpinan Kepala Madrasah Terhadap Kinerja Guru (Gramedia, Jakarta, 2017), pp. 22, 84.

[5] Peraturan Pemerintah Nomor 19 Tahun 2005 Tentang Standar Nasional Pendidikan

[6] Permendiknas Nomor 16 Tahun 2007 Tentang Standar Kualifikasi Akademik dan Kompetensi Guru.

[7] Peraturan Menteri Pendidikan Nasional Nomor 13 Tahun 2007 Tentang Standar Kepala Sekolah.

[8] Ghani, Abd. Rahman A., Metodologi Penelitian Tindakan Sekolah (Rajawali Press, Depok, 2014), pp. 40.

[9] Wirawan, Budaya dan Iklim Organisasi (Salemba Empin, Jakarta, 2007), pp. 25.

[10] Martini dan Yuliano, Komitmen Organisasi Ditinjau Berdasarkan Iklim Organisasi dan Motivasi Berprestasi. Jurnal Phronesis Vol. 2, Nomor 9 (2003).

[11] Sagala, Syaiful, Kemampuan Profesional Guru dan Tenaga Kependidikan (Alfabeta, Bandung, 2009), pp. 130.

[12] Bimo Walgito, Pengantar Psikologi Umum (Andi, Yogyakarta 2004), pp. 220.

[13] Siagian, Sondang P, Teori Motivasi dan Aplikasi (Rineka Cipta, Jakarta, 1995), pp. 138.

[14] Kompri, Motivasi Pembelajaran, Perspektif Guru dan Siswa (Remaja Rosdakarya, Bandung, 2015), pp. 60.

[15] Sahlan, Asnawi, Teori Motivasi, Dalam Pendekinan Psikologi Industri dan Organisasi (Studi Press, Jakarta, 2002), pp. 13.
[16] Tokan, Ratu Ile, Manajemen Penelitian Guru Untuk Pendidikan Bermutu (PT Grasindo, Jakarta, 2016), pp. 265-266.

[17] Emzir, Metodologi Penelitian Pendidikan, Kuantitinif dan Kualitinif (Raja Grafindo Persada, Depok, 2017), pp. 28.

[18] Sugiyono, Metode Penelitian Pendidikan, Pendekatan Kuantitatif, Kualitatif dan R\&D (Alfabeta Bandung, 2008), pp. 14.

[19] Sukardi, Metodologi Penelitian Pendidikan, Kompetensi dan Praktiknya (BumiAksara, Jakarta, 2008), pp. 146.

[20] Rismawan, Edi, Pengaruh Supervisi Kepala Sekolah dan Motivasi Berprestasi Guru Terhadap Kinerja Mengajar Guru. Jurnal UPI Vol. 22 Nomor 1 (2015).

[21] Gunawan, Hansen, et.all, The The influence of Headmaster's Supervision, Work Satisfaction, Work Motivation Again Teacher Performance in Privite Junior High School in Medan Perjuangan, Medan. Journal of Research \& Methode in Education (IOSR-JRME). Vol 7, Issue 5, Vol 1 (2017).

[22] Ghani, Abd. Rahman A., Herlina, Marliani, The The influence of School Principal Supervision and Work Motivation on the discipline of 18 public vocinional high school teachers in South Jakarta. The 1st UICIHSS (Uhamka Interninional Conference on Humanity and Social Science). Jakarta: Scholar Article (2017).

[23] NE Rohmawati, Pengaruh Iklim Organisasi Sekolah dan Motivasi Kerja Guru Terhadap Kinerja Guru, Studi di SD Negeri Kecamatan Ciamis. Jurnal Administrasi Pendidikan Olahraga, Pascasarjana Universitas Galuh Yogyakarta, Vol. 5 Nomor 2 (2017).

[24] Supardi, Kontribusi Kepala Madrasah, Iklim kerja dan Pemahaman Kurikulum Terhadap Kinerja Guru Madrasah Aliyah Propoinsi DKI Jakarta Tahun 2009-2010. Jurnal Pendidikan dan Kebudayaan, Kemdikbud, Vol 20, Nomor 1.133, Banten: Fakultas Keguruan dan Tarbiyah IAIN SMH (2014).

[25] Felayati, Micha, et all, Pengaruh Iklim Organisasi dan Kepuasan Kerja Terhadap Kinerja Guru Bimbingan dan Konseling. Jurnal JPPI, iicet. Vol. 2 No 1 (2016). 
[26] Rahmawati, Ika, Pengaruh Iklim Sekolah dan Motivasi Kerja Terhadap Kinerja Mengajar Guru SMK di Bandung. Jurnal UPI Vol. 21 Nomor 2 (2014).

[27] Suryati, et.all, The influence of Work Motivation and Work Climate on Teacher's Performance. International Journal of Progressive Science and
Technology (IJPSIN), Vol 20 No. 2, Palembang: ISSN 2509-0119 (2020).

[28] Andi, Fatmi, et all, Influence of School Principal And Organizational Climate Supervision On TeachersPerformance. Jurnal Internasional, Vol. 7 Edisi Juli (2018). 